\title{
Safety Measurements of Electromagnetic Fields Radiated from Mobile Base Stations in the Western Region of Saudi Arabia
}

\author{
Mouaaz Nahas, Mohammed T. Simsim \\ Department of Electrical Engineering, College of Engineering and Islamic Architecture, Umm Al-Qura University, Makkah, KSA. \\ Email: \{mmnahas, msimsim\}@uqu.edu.sa
}

Received June 29 ${ }^{\text {th }}$, 2011; revised September 20 ${ }^{\text {th }}$, 2011; accepted September $29^{\text {th }}, 2011$.

\begin{abstract}
Over the last decade, detrimental effects of human exposure to electromagnetic radiations have received widespread attention. Communications and Information Technology Commission (CITC) in Saudi Arabia has set guidelines and launched a national project-in collaboration with academic and research institutions - to perform measurements of the "electromagnetic fields" (EMFs) radiated from base stations of the mobile phone network. In keeping with its mission to address problems of the local community, Electrical Engineering (EE) department at Umm Al-Qura University (UQU) has been commissioned to conduct this project in the western region of Saudi Arabia. The project is concerned with measuring the strength of EMFs around base stations to locate the Maximum Peak Point (MPP). The aim of measurements is to ensure the site compliance with the CITC guidelines for human exposure to Radiofrequency (RF). This paper discusses possible health consequences caused by human exposure to RF radiations. Furthermore, it summarizes the results from 20 selective base stations located in Makkah, Madinah, Jeddah, Taif and Yanbu. The results show that EMF levels at all surveyed sites are far below the National Guidelines for public exposure to RF and that the MPPs are found within the distance range suggested in the CITC guidelines. The paper concludes by providing some useful comments and recommendations for RF sites surveyors.
\end{abstract}

Keywords: Electromagnetic Fields, Base Station, Maximum Peak Point, Radiofrequency, Power Density, Public Limit, Occupational Limit, National Guidelines

\section{Introduction}

Cellular wireless telephones have become ubiquitous. Over the past five years, the worldwide number of mobile phone users has doubled to reach 4.5 billions, where this figure is expected to grow up in 2011 by $10 \%$ to reach 5.6 billions [1]. A global mobile phone service penetration rate of $76.2 \%$ is estimated [2]. Wireless technology is based on extensive networks of base stations that connect users through radiofrequency (RF) signals. The rapid growth in the number of mobile phone subscribers has resulted in an increased number of base stations all over the world. Usually, base stations are more numerous in populated areas than in non-populated ones to serve as many users as possible while maintaining high service quality [3]. Today, the number of base stations worldwide has exceeded 1.4 million [4]. In Saudi Arabia, the number of mobile phone subscriptions in 2010 is estimated around 50 millions [5] with penetration rate of $172 \%$, which is much higher than the global penetration rate. This increase in the number of subscribers necessitates an expansion of the mobile phone network, thus more base stations are deployed. Available data for year 2007 shows that Mobily company, which commenced its service in 2005 as the second mobile phone service operator in the Kingdom, had 4843 base stations across the country [6].

Over the last decade, there has been a great deal of concern about possible health consequences caused by human exposure to RF in general and radiations from base stations in particular $[3,7,8]$. Generally, electromagnetic radiations have two types: Ionizing (high-frequency) and non-ionizing (low-frequency), where RF energy is a type of non-ionizing electromagnetic radiation [9]. It is believed that mobile phones produce RF energy which is too low to heat the body's tissues hence is unlikely to have the same impact on human health as those produced 
by ionizing radiations such as x-ray [9]. Nonetheless, there is still a need to determine the level of health risks caused by RF radiations. In [7], it was noted that while many studies address the impact of mobile phone radiations on the user body, only a few consider the effect of human exposure to base stations although such an effect may be greater as more parts of the body can suffer the RF energy absorption. Since cellular communication is considered as a new technology, the effect of public exposure to RF has been studied only over relatively short period of time and has not considered heath consequences of childhood exposures [8]. However, it is agreed that public exposures to permissible RF levels from both mobile telephones and base stations are unlikely to cause adverse effect on human health [10].

To control the amount of RF energy radiated from mobile base stations and hence reduce its consequences on human health, guidelines, practices and recommendations have been initiated by government agencies and international organizations. The most known guidelines are those recommended by the International Commission on Non-Ionizing Radiation Protection (ICNIRP) [11] and the Institute of Electrical and Electronics Engineers (IEEE) [12]. Such organizations set guidelines which restrict the amount of electromagnetic energy dissipated in the human body. These limits are provided for both general public and personnel working on site, i.e. occupational limits. Due to the fact that the environment for workers can somewhat be controlled, occupational exposure limit is generally higher than non-occupational (public) exposure limit in all international protection standards. The IEEE standard for RF exposure-called "Maximum Permissible Exposure" (MPE)—is adopted mainly in the United States and also in some other countries, while the standard established by ICNIRP is adopted mainly in West Europe.

The Communications and Information Technology Commission (CITC) in Saudi Arabia has set the National Guidelines to regulate the levels of RF emitted from mobile base stations across the whole country. These guidelines are based on those originated by ICNIRP. The RF field measurement methods required in the National Guidelines for determining compliance with the exposure limits are based on the International Electrotechnical Commission (IEC) and the IEEE standards [13].

This project is concerned with measuring the power density of the "electromagnetic fields" (EMFs) radiated from mobile base stations located in the western region of Saudi Arabia. The project is part of the research collaboration between Umm Al-Qura University (UQU) and the CITC. The main aim of conducting such meas- urements is to ensure that the EMFs radiated from the base stations comply with the guidelines set by the CITC for human exposure to RF. The guidelines are called "National Guidelines for Human Exposure to Radiofrequency Electromagnetic Fields" [13]. The guidelines suggest that radiations from base stations should not exceed the general public and occupational limits of 2 $\mathrm{W} / \mathrm{m}^{2}$ and $10 \mathrm{~W} / \mathrm{m}^{2}$, respectively, for the frequency range concerned with in this study (see Section 3 ). The focus of this paper is, however, on the effect of such radiations on the general public only.

As far as we know, previous work in this area has considered the radiation levels from sites located in other regions of Saudi Arabia and is not published. Similar projects have been carried out in neighboring countries. For example, in 2005, a project was carried out by Electrical Engineering students at Qatar University (QU) in collaboration with Qatar Telecom (Qtel) to measure the electromagnetic radiations from 3G mobile base stations [14]. Moreover, in [15], RF levels were measured and reported at several base stations providing Global System for Mobile Communication (GSM) services in the United Arab Emirates (UAE) in 2007. Results indicated that all measured EMF strengths were under the maximum permitted exposure for the general public according to the national as well as international standards. The measurement equipments used in the UAE project are same as those used in our project.

This paper presents measurement results of 20 base station sites located in Makkah, Madinah, Jeddah, Taif and Yanbu. These sites are operated by Saudi Telecom Company (STC), Mobily, Zain and Atheeb companies. Note that in this project we have completed the measurements for more than 100 different sites (so far). The sites for which results in this paper are presented form a representative subset that covers various possible conditions (i.e. location, base station structure, geographical nature and population of the ambient area of the site).

For confidentiality reasons, names of the operators, site names and exact locations are not provided in the paper. However, sites are divided into groups based on the cities in which they are placed and ordered chronologically according to the time they were surveyed within the city.

The paper is organized as follows. Section 2 discusses the effects of RF radiations on human body in a little more detail. In Section 3, the measurements methodology used in this study is outlined. Section 4 summarizes and analyzes the results presented in full in Appendix I. The overall paper conclusion is finally withdrawn in Section 5. 


\section{Impact of Human Exposure to RF Radiations}

With the significant increase in mobile phone usage, possible health risks related to RF exposure have become the subject of considerable attention $[8,16]$. This includes effects from exposure to both cell phones and base stations. Health concerns can be divided into two main categories: short-term and long-term health effects. The short-term effects include brain electrical activity, cognitive function, sleep, heart rate and blood pressure [17]. In contrast, the long-term effects are related to epidemicologic effects including cancer and brain tumours. Among all risks, the key concern has been with the cancer risk for populations living in the vicinity of base stations, but also effects on wellbeing are commonly raised [3]

The study reported in [8] has undertaken a wide review of epidemiologic effects of RFs on human health. The study considered studies of RF exposure from occupational sources, transmitters, and mobile phones and covered the possible effects of long-term exposure to RFs (defined as $100 \mathrm{kHz}$ to $300 \mathrm{GHz}$ ) on the risk of diseases such as cancer, heart disease, and adverse outcomes of pregnancy. It is concluded that results of epidemiologic studies give no firm evidence of a causal relation between RF exposure and any adverse health effect (see [8] for more details).

Besides the mentioned diseases, genetic effects have been a major issue which concerned many researchers [18]. Available studies in this area are based on human cytogenetic biomonitoring as well as in vitro and in vivo investigations. Generally, most investigations did not show any direct genotoxic effect from RF exposure: however, useful studies considered the high exposure levels resulting in an overall localized thermal effect (e.g. [19]). Even if RF radiations are not proven to be directly genotoxic, they can still be harmful by enhancing the genotoxicity of physical or chemical genotoxic agents [20, 21]. Overall, it is noted that despite many researches on the RF alleged genetic effects, no firm conclusion has been reached yet [18].

In [19], effect of severe cell phone exposure on brain glucose metabolism is evaluated. It is found that in healthy participants 50-minute cell phone exposure was associated with increased brain glucose metabolism in the region closest to the antenna.

Moreover, subjective symptoms, including tinnitus, headache, dizziness, fatigue, sensations of warmth, dysesthesia of the scalp, visual symptoms, memory loss, and sleep disturbance have also been investigated in as- sociation with mobile phone use [22,23]. Such studies are highly susceptible to recall bias, therefore experimental studies on symptoms related to mobile phone use have also been carried out $[24,25]$.

Despite a great deal of researches conducted in this area, the results have still been inconclusive [3]. Therefore, it can be concluded that no firm evidence has been provided for a direct effect of RF exposure on the body health, hence, further investigations are still to be considered. Nonetheless, we should bear in mind that due to the new emergence of cellular communication technology, the effect of public exposure to RF has been studied only over relatively short period of time and heath consequences of childhood exposures have not been considered [8]. Despite any potential health risks, it is agreed that public exposures to "permissible" RF levels (as defined in the international standards) are unlikely to cause adverse impacts on human health [10].

\section{Measurements Methodology}

The measurements methodology adopted in this project to assess each site has been taken from the CITC guidelines [13].

\subsection{Preliminary Site Survey}

At each site, an initial investigation is conducted using a broadband RF exposure meter with isotropic field probes (appropriate to the frequency range of the services provided by the evaluated site). The electric field strength is recorded for each site. The purposes of initial site survey are:

- To ensure that RF field emission from each site does not exceed the public limits of $2 \mathrm{~W} / \mathrm{m}^{2}$ (as stated in the National Guidelines) in any area to which the general public has access outside the site boundary.

- To find the location of the Maximum Peak Point (MPP) around the site in areas accessible by the general public.

\subsection{Broadband Survey}

The NBM-550 broadband field meter produced by NARDA, Germany, is chosen as the measurement equipment for this part. It can be used to measure non-ionizing radiation accurately, measuring frequency range from $100 \mathrm{kHz}$ to $60 \mathrm{GHz}$ with the various probes. Figure 1 shows picture for this instrument.

After the MPP is located, the NBM-550 meter and isotropic field probe are mounted on a non-conductive tripod at height of $1.75 \mathrm{~m}$ above the ground. The electric field strength (power density) is then recorded for the interval of six minutes. 


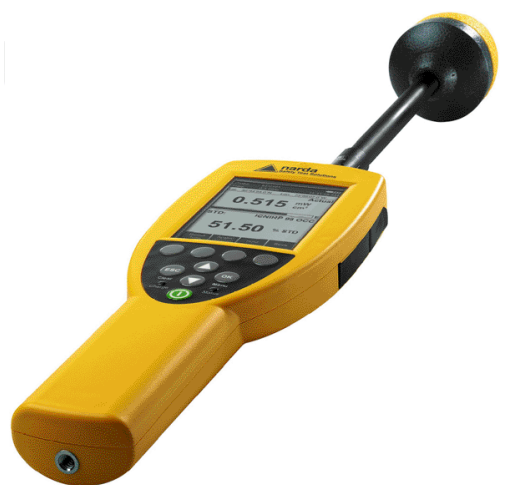

Figure 1. Narada broadband filed meter (NBM-550).

\subsection{Narrowband Survey}

The SRM300 narrowband frequency selective radiation meter produced by NARDA, Germany, is used as the measurement equipment for this part. The triaxial antenna allows isotropic (non-directional) measurements from $50 \mathrm{MHz}$ to $3 \mathrm{GHz}$, covering $\mathrm{FM}$ radio up to the W-CDMA and UMTS services. Figure 2 shows picture for this instrument. In this part, the SRM300 meter is set to sweep each frequency range continuously for a period of up to six minutes and the results are recorded electronically for later analysis.

Since none of the measured sites exceeded the public limit exposure, narrowband measurements were only performed at some selective sites for consistency checking purposes. These measurements are not presented in the paper.

\subsection{Safety and Troubleshooting}

The broadband and narrowband instruments have battery charging time of one hour by AC supply. Full charging allows the battery to work for six hours only. This required making sure that the battery was fully charged before going out to the site and pursuing the measurements. The discharging period was also taken into account when two sites were decided to be surveyed con-

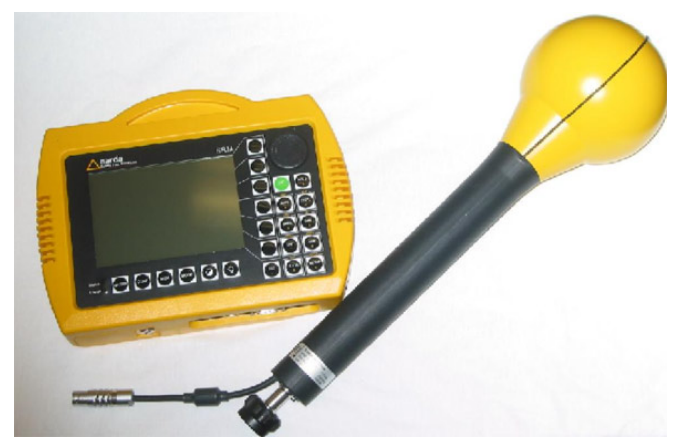

Figure 2. Narda narrowband field meter (SRM3000). secutively on the same day; as each site takes an average time of three hours.

The broadband device has a GPS module attached to it. The GPS sometimes does not work. So a separate GPS device was used throughout this project to handle such a problem if it happens.

\subsection{Measurement Steps}

The first step in the survey is to gather information about the sites selected by the CITC using the data sheet provided. Google earth is then used to identify the location of each site by its coordinates. Upon arrival to the site, the first action is to check the name and number of the site (usually displayed) and the coordinates using the GPS module. The next step is to select an appropriate sector antenna to carry out the measurements (each site usually has three main sectors). Figure 3 illustrates different sector antenna structures which were found in our surveys. The selected antenna must have enough space along its transmission direction to allow free movement for determining the MPP location easily. Preliminary, broadband and narrowband surveys were then conducted.

Note that there were two main tower structures: Green Field (GF) and Rooftop (RT). The GF tower is mounted on the ground and all antennas are fixed at the top of the tower. In contrast, the RT tower is set on the roof of a building and sometimes the antennas are not fixed on a single tower: instead, they are split apart. The GF structures are usually surrounded by a protection fence where the RT ones are not (the roof door is however locked up for preventing access to the site).
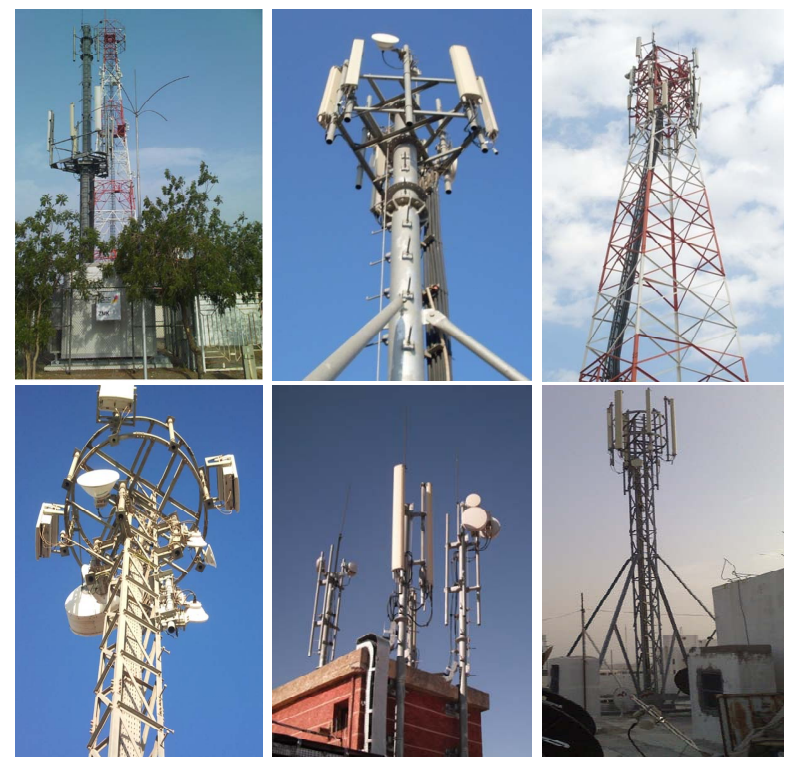

Figure 3. Different structures of base stations observed in our surveys. 
After the MPP is determined, we move to the front and measure the power density for five points with five meters distance between each two points. This process is then repeated to the right, left and behind the maximum point. Please note that the distances and the angles are determined using Google Earth (Figure 4). All measurements are recorded in Watt per meter squared $\left(\mathrm{W} / \mathrm{m}^{2}\right)$, to allow direct comparison with CITC guidelines. The guideline limit used for comparison is $2 \mathrm{~W} / \mathrm{m}^{2}$ which is the threshold level. Further measurements and analysis are required to identify the field strength of individual RF sources. After that, analysis and results are recorded in the technical report written for the surveyed site. Note that the CITC requires that a technical report is submitted for each site that summarizes the site information, measurement details, site photos, results and overall conclusion. Typically, the report for each site must be submitted within couple of weeks after completion of the survey.

\section{Results and Analysis}

The detailed results are presented in Appendix I. This section rather provides a summary and analysis of the key results.

Tables 1-5 in Appendix I present the results for sites measured in Makkah, Jeddah, Taif, Madinah and Yanbu, respectively. In each table, the first four columns provide site details as follows: measurement order, brief description (in terms of base station structure, tower height and population level), date and time in which the measurements were conducted, and services provided by the site. The following three columns provide the measurement results as follows: the horizontal distance between the MPP and the base station, the power density at the MPP and finally the percentage of the maximum power density from the general public limit as suggested in the CITC guidelines.

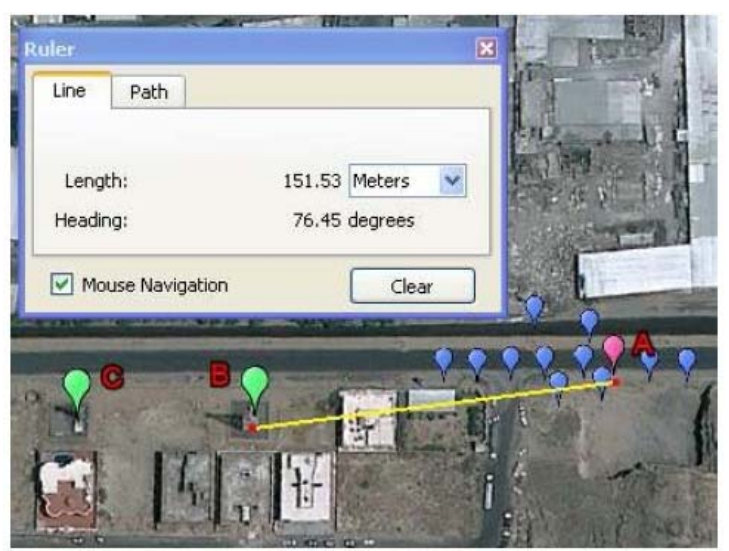

Figure 4. Google Earth ruler for horizontal distance determination.
It can clearly be seen from the results that the maximum and minimum power densities in the reported sites were $0.0981 \mathrm{~W} / \mathrm{m}^{2}$ and $0.0007 \mathrm{~W} / \mathrm{m}^{2}$, respectively. Based on these figures, the maximum electromagnetic radiation was approximately $4.9 \%$ of the public limits of the $\mathrm{Na}$ tional Guidelines. This confirms that all audited sites comply with the standards of the CITC in terms of the amount of EMFs that the base station is radiating. Please note that the power density measured at all other sites (which are not included in this paper) fall between these two figures.

When comparing the locations of the MPPs with respect to the base station locations, we can see that the maximum horizontal distance was $285 \mathrm{~m}$ while the minimum distance was $70.81 \mathrm{~m}$. These figures show that all MPPs fall within the distance range estimated by the CITC which is 50 to $300 \mathrm{~m}$ [26].

It can also be noticed from the trend of results that the amount of radiated power somewhat relates to the services provided by the facility (as different sites provide different wireless services, for example, GSM900, GSM1800 and UMTS). Moreover, EMF strengths are often lower in areas with low population than in high population areas. Note that the power density at any point in the bore-site direction of the antenna is a function of the number of transmitters $N$, the maximum radiated power from each transmitter $P_{t}$ (which is often equal in all transmitters), antenna gain $G$ and the total distance from the point to the reference antenna $d$ [26]. The power density $S$ can be calculated using Equation (1):

$$
S=\frac{N P_{t} G}{4 \pi d^{2}}
$$

Furthermore, it should be pointed out that the distance of the MPP depends on a number of parameters including: the antenna height, the 3-dB beamwidth and tilt angle of the antenna.

The differences in the power density values are due to the variation in site characteristics and general surroundings of each individual site. Typically, meaningful comparison of results is only achieved if measurement conditions as well as site characteristics-in terms of (for example) geographical nature, vicinity population, site specifications, survey time and weather-are all identical which is not the case in practical scenarios. However, the results presented in the paper (and the general comparesons provided) are still valid for the purpose of this project.

\section{Conclusions}

This paper provided the broadband measurements of 20 different mobile bases stations located in the western 
region of Saudi Arabia. The project is part of the collaboration between Umm Al Qura University (UQU) and the Communications and Information Technology Commission (CITC). The results presented in the paper demonstrate that all surveyed sites comply with the National Guidelines for human exposure to radiofrequency; hence no further "narrowband" surveys were required.

The presented results show that the RF radiation levels from base station antennas were far below the permissible exposure limit set by the CITC guidelines and thus fall within the safe limits established by the international standard organizations.

We conclude the paper by providing some useful recommendations extracted from the UQU measurements team experience. First, it has been found that performing such kind of surveys requires good interpersonal and communication skills to deal with curiousness of people and circumvent any problem which might occur due to lack of familiarity among the general public. An important issue to consider is that the measurements team should always have an official letter which states the purpose of their job and lists the names of the team members. Also, it is worth noting that such measurements require a high degree of accuracy and integrity as the results are directly related to the safety of human being. The ten items of the IEEE code of ethics [27] must be followed while conducting such a project.

Furthermore, the UQU measurements team involves professors, engineers and students (in senior levels). Students working on their graduating project usually form the key part of the team. It is found that students participating in this project are gaining a wide range of skills, e.g. problem-solving, teamwork, technical writing, lifelong learning, understanding ethical responsibilities as well as analytical and critical thinking. Acquiring such skill set helps our graduates to meet the objectives of the EE program and attain a broad range of the program outcomes [28].

Note that measurements presented in this paper are part of an ongoing project. More sites in the western region of Saudi Arabia are still under survey by the UQU measurements team.

\section{Acknowledgements}

Authors would like to thank the Communications and Information Technology Commission (CITC) in Saudi Arabia for sponsoring this project. Special gratitude and appreciation to Engr. Abdullah Al-Darrab, the Deputy Governor for Technical Affairs and Engr. Tariq Al-Amri, Project Leader on National Guidelines for Human Exposure to Radiofrequency Electromagnetic Fields, from CITC for the valuable support and encouragement. Also, the authors acknowledge the important participation of colleagues and students from the Electrical Engineering department at Umm Al-Qura University to carry out sites' measurement and in preparing technical reports.

\section{REFERENCES}

[1] European Information Technology Observatory (ETO), "Press Release," 2010. http://www.eito.com/reposi/PressReleases/eito-pr-2010081 1.pdf

[2] International Telecommunication Union (ITU), "ITU Mexican Market Overview,” 2010.

http://www.itu.int/plenipotentiary/2010/newsroom/backgr ounders/mexican-market.html

[3] J. F. Viel, S. Clerc, C. Barrera, R. Rymzhanova, M. Moissonnier, M. Hours and E. Cardis, "Residential Exposure to Radiofrequency Fields from Mobile Phone Base Stations, and Broadcast Transmitters: A Population-Based Survey with Personal Meter," 2009.

http://oem.bmj.com/content/66/8/550.full

[4] World Health Organization (WHO) Media Center, "Electromagnetic Fields and Public Health: Base Stations and Wireless Technologies,” 2006.

http://www.mobilemastinfo.com/2006-2008/who-factshee t-electromagnetic-fields-and-public-health-base-stations-a nd-wireless-technologies.html

[5] Communication and Information Technology Commission (CITC), "ICT Indicators in K.S.A (1st Half-2010) Mobile Telecommunications Market,” 2010.

http://www.citc.gov.sa/NR/rdonlyres/547B2AB2-0738-4 B05-ADFC-9CAB5FEAEF68/0/ICTIndicatorsinKSA_Fir stHalf_2010_English.pdf

[6] Mobily, “Annual Report-2008,” 2008. http://www.mobily.com.sa/pv_obj_cache/pv_obj_id_5F4 AF59AA6CDBE2E5B99423E379DCF013AC23100/filen ame/Mobily\%20Annual\%20Report\%202008.pdf

[7] A. M. Martinez-Gonzalez, A. Fernandez-Pascual, E. de los Reyes, W. Van Loock, C. Gabriel and D. SanchezHernandez, "Practical Procedure for Verification of Compliance of Digital Mobile Radio Base Stations to Limitations of Exposure of the General Public to Electromagnetic Fields," IEE Proceedings on Microwaves, Antennas and Propagation, Vol. 149, 2002, pp. 218-228. doi:10.1049/ip-map:20020569

[8] A. Ahlbom, A. Green, L. Kheifets, D. Savitz and A. Swerdlow, "Epidemiology of Health Effects of Radiofrequency Exposure,” Environmental Health Perspectives, Vol. 112, No. 17, 2004, pp. 1741-1754. doi:10.1289/ehp.7306

[9] U.S. Food and Drug Administration (FDA), "RadiationEmitting Products: Reducing Exposure: Hands-Free Kits and Other Accessories,” 2009.

http://www.fda.gov/Radiation-EmittingProducts/Radiatio nEmittingProductsandProcedures/HomeBusinessand-Entertainment/CellPhones/ucm116293.htm 
[10] P. A. Valberg1, T. E. Deventer and M. H. Repacholi, "Workgroup Report: Base Stations and Wireless Networks-Radiofrequency (RF) Exposures and Health Consequences,” Environmental Health Perspectives, Vol. 115, No. 3, 2007, pp. 416-424. http://ehp03.niehs.nih.gov/article/fetchArticle.action?artic leURI=info:doi/10.1289/ehp.9633

[11] International Commission on Non-Ionizing Radiation Protection (ICNIRP), "Guidelines for Limiting Exposure to Time-Varying Electric, Magnetic, and Electromagnetic Fields (up to $300 \mathrm{GHz}$ )," Health Physics, Vol. 74, No. 4, 1998, pp. 494-522. doi:10.1097/HP.0b013e3181f06c86

[12] IEEE International Committee on Electromagnetic Safety, "IEEE Standard for Safety Levels with Respect to Human Exposure to Radio Frequency Electromagnetic Fields, 3 kHz to 300GHz," (IEEE C95.1-2005) 2006. http://rfsafetysolutions.com/PDF\%20Files/C95.1-2005_C overPage.pdf

[13] CITC, "National Guidelines for Human Exposure to Radiofrequency Electromagnetic Fields,” 2009. http://citc.gov.sa/English/RulesandSystems/RegulatoryDo cuments/Electro-magneticfields/Documents/TA\%20113\% 20E\%20\%20National\%20Guidelines\%20for\%20Human \%20Exposure\%20to\%20Radiofrequency\%20Electromagn etic\%20Fields.pdf

[14] M. O. Hasna, "Research in Undergraduate Education at Qatar University: EE Department Experience,” 37th ASEE/ IEEE Frontiers in Education Conference, Milwaukee, 10-13 October 2007, S4B-13 - S4B-16.

[15] A. K. Al-Tamimi, and F. A. Al Mazrouei, "Safety Management of RF Radiation Sources in the United Arab Emirates," Practice Periodical of Hazardous, Toxic, and Radioactive Waste Management, Vol. 11, No. 3, 2007, pp. 184-190. doi:10.1061/(ASCE)1090-025X(2007)11:3(184)

[16] N. D. Volkow, D. Tomasi, G. J. Wang, P. Vaska, J. S. Fowler, F. Telang, D. Alexoff, J. Logan and C. Wong, "Effects of Cell Phone Radiofrequency Signal Exposure on Brain Glucose Metabolism,” Journal of American Medical Association, Vol. 305 , No. 8, 2011, pp. 808-813. doi:10.1001/jama.2011.186

[17] World Health Organization (WHO) Media Center, "Electromagnetic Fields and Public Health: Mobile Phones," 2011. http://www.who.int/mediacentre/factsheets/fs193/en/
[18] L. Verschaeve, "Review of RFR-Genotoxicity Studies," 2010 Asia-Pacific Symposium on Electromagnetic Compatibility (APEMC), Beijing, 12-16 April 2010, pp. 9-12.

[19] V. Garaj-Vrhovac, A. Fucic and D. Horvat, "The Correlation between the Frequency of Micronuclei and Specific Chromosome Aberrations in Human Lymphocytes Exposed to Microwave Radiation in Vitro," Mutation Research, Vol. 281, No. 3, 1992, pp. 181-186. doi:10.1093/mutage/geh042

[20] L. Verschaeve, "Genetic Effects of Radiofrequency Radiation (RFR)," Toxicology and Applied Pharmacolog, Vol. 207, No. 2, 2005, pp. 336-341. doi:10.1016/j.taap.2005.03.028

[21] P. Heikkinen, "Studies on Cancer-Related Effects of Radiofrequency Electromagnetic Fields,” Ph.D. Thesis, Kuopio University, Finland, 2006.

[22] S. E. Chia, H. P. Chia and J. S. Tan, "Prevalence of Headache among Handheld Cellular Telephone Users in Singapore: A Community Study,” Environmental Health Perspectives, Vol. 108, No. 11, 2000, pp. 1059-1062. doi:10.1289/ehp.001081059

[23] G. Oftedal, J. Wilen, M. Sandstrom and K. H. Mild, "Symptoms Experienced in Connection with Mobile Phone Use," Occupational Medicine, Vol. 50, No. 4, 2000, pp. 237-245. doi:10.1093/occmed/50.4.237

[24] M. Hietanen, A. M. Hämäläinen and T. Husman, "Hypersensitivity Symptoms Associated with Exposure to Cellular Telephones: No Causal Link,” Bioelectromagnetics, Vol. 23, No. 4, 2002, pp. 264-270.

[25] M. Koivisto, C. Haarala, C. M. Krause, A. Revonsuo, M. Laine and H. Hämäläinen, "GSM Phone Signal Does not Produce Subjective Symptoms,” Bioelectromagnetics, Vol. 22, No. 3, 2001, pp. 212-215. doi:10.1002/bem.41

[26] CITC and King Saud University, "Measurement Procedures for Electromagnetic Radiations from Wireless Base Stations,” Technical Report, 2008

[27] IEEE, “IEEE Code of Ethics,” 2011. https://www.ieee.org/about/corporate/governance/p7-8.html

[28] Electrical Engineering Department at UQU, "Electrical Engineering (EE) Program Outcomes,” 2010. http://uqu.edu.sa/engineering-architecture-en/en/167029 


\section{Appendix I}

\section{Measurement Results}

Tables 1-5 provide the detailed results from all sites considered in this paper. Results include: site number (based on chronological order), brief site description, date and time of measurement, horizontal distance of MPP from the base station and power density at the MPP.

Table 1. Results from sites located in Makkah.

\begin{tabular}{|c|c|c|c|c|c|c|}
\hline $\begin{array}{l}\text { Site } \\
\text { Order }\end{array}$ & $\begin{array}{l}\text { Brief Site } \\
\text { Description }\end{array}$ & $\begin{array}{l}\text { Date \& Time } \\
\quad(24 \mathrm{~h})\end{array}$ & $\begin{array}{l}\text { Services } \\
\text { on site }\end{array}$ & $\begin{array}{c}\text { Horizontal Distance } \\
\text { between MPP and } \mathrm{BS}^{1}(\mathrm{~m})\end{array}$ & $\begin{array}{l}\text { Power Density at } \\
\operatorname{MPP}\left(\mathrm{W} / \mathrm{m}^{2}\right)\end{array}$ & $\begin{array}{l}\text { Percentage of } \\
\text { public limit \% }\end{array}$ \\
\hline 1. & $\begin{array}{c}\mathrm{RT} \\
21 \mathrm{~m} \\
\text { High population } \\
\text { Rough area }\end{array}$ & $\begin{array}{l}\text { 26/11/2009 } \\
16: 00\end{array}$ & $\begin{array}{l}\text { GSM } 900 \\
\text { GSM } 1800\end{array}$ & 165 & 0.0145 & 0.725 \\
\hline 2. & $\begin{array}{c}\text { RT } \\
23 \mathrm{~m} \\
\text { High population } \\
\text { Plain area }\end{array}$ & $\begin{array}{l}\text { 01/04/2010 } \\
17: 00\end{array}$ & $\begin{array}{l}\text { GSM } 900 \\
\text { GSM } 1800\end{array}$ & 102 & 0.01922 & 0.961 \\
\hline 3. & $\begin{array}{c}\text { GF } \\
30 \mathrm{~m} \\
\text { High population } \\
\text { Plain area }\end{array}$ & $\begin{array}{l}29 / 04 / 2010 \\
17: 10\end{array}$ & $\begin{array}{l}\text { GSM } 900 \\
\text { GSM } 1800 \\
\text { UMTS }\end{array}$ & 70.81 & 0.0380 & 1.897 \\
\hline 4. & $\begin{array}{c}\text { GF } \\
37 \mathrm{~m} \\
\text { Low population } \\
\text { Plain area }\end{array}$ & $\begin{array}{l}30 / 05 / 2010 \\
11: 10\end{array}$ & GSM 900 & 90 & 0.0007 & 0.037 \\
\hline 5. & $\begin{array}{c}\text { GF } \\
27 \mathrm{~m} \\
\text { Medium popula- } \\
\text { tion } \\
\text { Plain area }\end{array}$ & $\begin{array}{l}\text { 30/11/2010 } \\
16: 00\end{array}$ & $\begin{array}{l}\text { GSM } 900 \\
\text { GSM } 1800\end{array}$ & 106 & 0.0981 & 4.905 \\
\hline
\end{tabular}

${ }^{1}$ BS: Base Station.

Table 2. Results from sites located in Jeddah.

\begin{tabular}{|c|c|c|c|c|c|c|}
\hline $\begin{array}{l}\text { Site } \\
\text { Order }\end{array}$ & $\begin{array}{l}\text { Brief Site } \\
\text { Description }\end{array}$ & $\begin{array}{l}\text { Date \& Time } \\
\quad(24 \mathrm{~h})\end{array}$ & $\begin{array}{l}\text { Services } \\
\text { on site }\end{array}$ & $\begin{array}{c}\text { Horizontal Distance } \\
\text { between MPP and BS (m) }\end{array}$ & $\begin{array}{l}\text { Power Density at } \\
\operatorname{MPP}\left(\mathrm{W} / \mathrm{m}^{2}\right)\end{array}$ & $\begin{array}{l}\text { Percentage of } \\
\text { public limit \% }\end{array}$ \\
\hline 1. & $\begin{array}{c}\text { RT } \\
23 \mathrm{~m} \\
\text { Medium population } \\
\text { Plain area }\end{array}$ & $\begin{array}{l}17 / 04 / 2010 \\
06: 30\end{array}$ & $\begin{array}{l}\text { GSM } 900 \\
\text { GSM } 1800\end{array}$ & 285 & 0.0096 & 0.482 \\
\hline 2. & $\begin{array}{c}\text { GF } \\
35 \mathrm{~m} \\
\text { Low population } \\
\text { Plain area }\end{array}$ & $\begin{array}{l}01 / 05 / 2010 \\
12: 00\end{array}$ & $\begin{array}{l}\text { GSM } 900 \\
\text { UMTS }\end{array}$ & 104 & 0.0026 & 0.130 \\
\hline 3. & $\begin{array}{c}\text { GF } \\
26.6 \mathrm{~m} \\
\text { Low population } \\
\text { Plain area }\end{array}$ & $\begin{array}{l}31 / 05 / 2010 \\
18: 00\end{array}$ & $\begin{array}{l}\text { GSM } 900 \\
\text { UMTS }\end{array}$ & 79 & 0.0031 & 0.157 \\
\hline 4. & $\begin{array}{c}\text { RT } \\
21 \mathrm{~m} \\
\text { Medium population } \\
\text { Plain area }\end{array}$ & $\begin{array}{l}14 / 07 / 2010 \\
11: 00\end{array}$ & Not provided & 200 & 0.0148 & 0.739 \\
\hline
\end{tabular}


Region of Saudi Arabia

Table 3. Results from sites located in Taif.

\begin{tabular}{|c|c|c|c|c|c|c|}
\hline $\begin{array}{l}\text { Site } \\
\text { Order }\end{array}$ & $\begin{array}{l}\text { Brief Site } \\
\text { Description }\end{array}$ & $\begin{array}{l}\text { Date \& Time } \\
(24 \mathrm{~h})\end{array}$ & $\begin{array}{l}\text { Services } \\
\text { on site }\end{array}$ & $\begin{array}{c}\text { Horizontal Distance } \\
\text { between MPP and BS (m) }\end{array}$ & $\begin{array}{l}\text { Power Density at } \\
\text { MPP }\left(\mathrm{W} / \mathrm{m}^{2}\right)\end{array}$ & $\begin{array}{l}\text { Percentage of } \\
\text { public limit \% }\end{array}$ \\
\hline 1. & $\begin{array}{c}\text { GF } \\
20 \mathrm{~m} \\
\text { Medium population } \\
\text { Rough area }\end{array}$ & $\begin{array}{l}\text { 18/04/2010 } \\
07: 00\end{array}$ & Not provided & 130 & 0.0011 & 0.055 \\
\hline 2. & $\begin{array}{c}\text { RT } \\
20 \mathrm{~m} \\
\text { High population } \\
\text { Plain area }\end{array}$ & $\begin{array}{l}\text { 18/04/2010 } \\
09: 30\end{array}$ & Not provided & 77 & 0.011 & 0.550 \\
\hline 3. & $\begin{array}{c}\text { RT } \\
30 \mathrm{~m} \\
\text { Medium population } \\
\text { Plain area }\end{array}$ & $\begin{array}{c}18 / 04 / 2010 \\
17: 00\end{array}$ & $\begin{array}{l}\text { GSM } 900 \\
\text { UMTS }\end{array}$ & 144 & 0.0025 & 0.125 \\
\hline 4. & $\begin{array}{c}\text { RT } \\
30 \mathrm{~m} \\
\text { Medium population } \\
\text { Plain area }\end{array}$ & $\begin{array}{c}09 / 06 / 2010 \\
17: 00\end{array}$ & $\begin{array}{l}\text { GSM } 900 \\
\text { UMTS }\end{array}$ & 70.81 & 0.0145 & 0.725 \\
\hline
\end{tabular}

Table 4. Results from sites located in Madinah.

\begin{tabular}{|c|c|c|c|c|c|c|}
\hline $\begin{array}{l}\text { Site } \\
\text { Order }\end{array}$ & $\begin{array}{l}\text { Brief Site } \\
\text { Description }\end{array}$ & $\begin{array}{l}\text { Date \& Time } \\
\quad(24 \mathrm{~h})\end{array}$ & $\begin{array}{l}\text { Services } \\
\text { on site }\end{array}$ & $\begin{array}{c}\text { Horizontal Distance } \\
\text { between MPP and BS (m) }\end{array}$ & $\begin{array}{l}\text { Power Density at } \\
\text { MPP }\left(\mathrm{W} / \mathrm{m}^{2}\right)\end{array}$ & $\begin{array}{l}\text { Percentage of } \\
\text { public limit \% }\end{array}$ \\
\hline 1. & $\begin{array}{c}\text { GF } \\
\text { 35m } \\
\text { Low population } \\
\text { Plain area }\end{array}$ & $\begin{array}{l}08 / 12 / 2010 \\
10: 00\end{array}$ & UMTS & 196.59 & 0.0046 & 0.230 \\
\hline 2. & $\begin{array}{c}\text { RT } \\
42.5 \mathrm{~m} \\
\text { Low population } \\
\text { Plain area }\end{array}$ & $\begin{array}{l}08 / 12 / 2010 \\
14: 15\end{array}$ & $\begin{array}{l}\text { GSM } 900 \\
\text { UMTS }\end{array}$ & 133.50 & 0.0032 & 0.160 \\
\hline 3. & $\begin{array}{c}\text { GF } \\
30 \mathrm{~m} \\
\text { Low population } \\
\text { Plain area }\end{array}$ & $\begin{array}{l}\text { 09/12/2010 } \\
08: 45\end{array}$ & $\begin{array}{l}\text { GSM } 900 \\
\text { GSM } 1800 \\
\text { UMTS }\end{array}$ & 133.50 & 0.0034 & 0.170 \\
\hline 4. & $\begin{array}{c}\text { RT } \\
21 \mathrm{~m} \\
\text { Medium population } \\
\text { Plain area }\end{array}$ & $\begin{array}{l}\text { 10/12/2010 } \\
\text { 08:00 }\end{array}$ & $\begin{array}{l}\text { GSM } 900 \\
\text { GSM } 1800\end{array}$ & 119 & 0.0043 & 0.215 \\
\hline
\end{tabular}

Table 5. Results from sites located in Yanbu.

\begin{tabular}{|c|c|c|c|c|c|c|}
\hline $\begin{array}{l}\text { Site } \\
\text { Order }\end{array}$ & $\begin{array}{c}\text { Brief Site } \\
\text { Description }\end{array}$ & $\begin{array}{l}\text { Date \& Time } \\
\quad(24 \mathrm{~h})\end{array}$ & $\begin{array}{l}\text { Services } \\
\text { on site }\end{array}$ & $\begin{array}{c}\text { Horizontal Distance } \\
\text { between MPP and BS (m) }\end{array}$ & $\begin{array}{l}\text { Power Density at } \\
\operatorname{MPP}\left(\mathrm{W} / \mathrm{m}^{2}\right)\end{array}$ & $\begin{array}{l}\text { Percentage of } \\
\text { public limit \% }\end{array}$ \\
\hline 1. & $\begin{array}{c}\text { RT } \\
20 \mathrm{~m} \\
\text { Medium population } \\
\text { Plain area }\end{array}$ & $\begin{array}{l}\text { 19/04/2010 } \\
\text { 08:00 }\end{array}$ & GSM 900 & 74 & 0.0072 & 0.36 \\
\hline 2. & $\begin{array}{c}\text { RT } \\
34.5 \mathrm{~m} \\
\text { Medium population } \\
\text { Plain area }\end{array}$ & $\begin{array}{c}19 / 04 / 2010 \\
13: 00\end{array}$ & Not provided & 70 & 0.0050 & 0.25 \\
\hline 3. & $\begin{array}{c}\text { GF } \\
35 \mathrm{~m} \\
\text { Medium population } \\
\text { Plain area }\end{array}$ & $\begin{array}{c}19 / 04 / 2010 \\
16: 00\end{array}$ & Not provided & 149 & 0.0124 & 0.62 \\
\hline
\end{tabular}

